\title{
Perdebatan Kepentingan Kebijakan Digitalisasi Penyiaran di Indonesia (Studi Kasus Perumusan Kebijakan Digitalisasi Penyiaran pada RUU Penyiaran di DPR 2009-2014 dan 2014-2019)
}

Interest Disputes of Broadcasting Digitalization Policy in Indonesia (A Case Study on the Formulation Of Broadcasting Digitalization Policy in the Broadcasting Bill in the Parliamentary Periods of 2009-2014 And 2014-2019)

\section{Ahmad Budiman}

Pusat Penelitian, Badan Keahlian DPR RI

email:a.budiman69@gmail.com

\begin{tabular}{l}
\hline Riwayat Artikel \\
\hline Diterima: 12 Februari 2020 \\
Direvisi: 9 Maret 2020 \\
Disetujui: 21 April 2020 \\
doi: $10.22212 /$ jp.v11i1.1613
\end{tabular}

Abstract

The formulation and discussion on broadcasting digitalization, as one of the aspects of the Revised Broadcasting Bill, has been well underway since the Parliamentary Period of 2009-2014, and continued in the following Period of 2014-2019. The long period of deliberation of the policy shows that it tries to accommodate many interests. The research question raised in this study is concerned with the contestation arising in the formulation of broadcasting digitalization policy in Indonesia. This study aims to describe the research question regarding the debate over differing interests that occurred in formulating broadcasting digitalization policy in Indonesia. The research method used in this study is a case study qualitative method. Based on the results of the study, in the 2009-2014 period, a debate of interests occurred between the House and the Government, with regard to the rightful provider of multiplex services, has impacts on different definitions of broadcasting. The House maintains that multiplex provider rights should be given to multiplex broadcast providers (LPPM), whereas the Government believes that the rights should be given to IPP-licensed broadcasters. Commission I of the House in the 2014-2019 period formulated the policy of broadcasting digitalization in detail, especially with regard to the matter of the Government's obligation to formulate the frequency allocation map in every broadcast area, migration model, ASO in every broadcast area and at the national level, digital dividend, and multiplexing fees. The proposed migration model was the single mux model, but it was opposed by the Legislation Committee of the House (Baleg), which proposed the hybrid mux migration model. Baleg believed that the single mux model would potentially create monopolistic practices. Furthermore, the state-owned TVRI has not been equipped with up-to-date broadcasting infrastructure and high-skilled human resources. Certainty in the frequency allocation map calculation in every broadcasting area, prospective digital dividend, and the prospect of broadcast companies must be the main foundation in determining the most appropriate digital migration model in Indonesia. It is certainly not impossible if Indonesia may even have its own unique migration model. Together, the House and the Government have to discuss and finish the Bill on Broadcasting as soon as possible for broadcasting digitalization to take place, for the benefit of the people and the nation of Indonesia.

Keywords: Debate on interest; Broadcasting Digitalization Policy; Bill of Broadcasting. 


\begin{abstract}
Abstrak
Perumusan dan pembahasan kebijakan digitalisasi penyiaran yang menjadi salah satu materi dari perumusan penggantian UU Penyiaran, sudah dilakukan sejak DPR periode 2009-2014 dan dimulai kembali pada DPR periode 2014-2019. Lamanya perumusan dan pembahasan kebijakan digitalisasi penyiaran, menunjukkan materi ini memang sangat sarat kepentingan. Pertanyaan penelitian yang diajukan dalam penelitian ini yaitu bagaimana kontestasi perdebatan kepentingan yang terjadi dalam merumuskan kebijakan tentang digitalisasi penyiaran di Indonesia? Penelitian ini bertujuan mendeskripsikan pertanyaan penelitian mengenai kontestasi perdebatan kepentingan yang terjadi dalam merumuskan kebijakan tentang digitalisasi penyiaran di Indonesia. Metode penelitian yang digunakan dalam penelitian ini yaitu metode kualitatif studi kasus mengenai perdebatan kepentingan perumusan kebijakan digitalisasi penyiaran yang terjadi pada DPR periode 2009-2014 dan DPR periode 2014-2019. Berdasarkan hasil penelitian, pada DPR periode 2009-2014, perdebatan kepentingan terjadi antara DPR dengan Pemerintah, terkait dengan siapa yang berhak menjadi penyelenggara multipeksing yang berdampak juga pada definisi penyiaran yang berbeda. DPR tetap menyatakan penyelenggara multipleksing diserahkan kepada lembaga penyelenggara penyiaran multipleksing (LPPM). Sedangkan Pemerintah menyerahkan penyelenggara kepada lembaga penyiaran yang telah memiliki IPP. DPR periode 2014-2019 melalui Komisi I DPR, merumuskan secara rinci kebijakan digitalisasi penyiaran terkait kewajiban Pemerintah untuk menyusun peta alokasi frekuensi di setiap wilayah siar, model migrasi, ASO disetiap wilayah siar dan secara nasional, digital deviden, dan tarif penyelanggaraan multipleksing. Model migrasi yang diajukan yaitu model single mux, namun mendapatkan pertentangan dari Baleg DPR yang mengajukan model migrasi hybrid mux. Baleg menilai single mux berpotensi memunculkan praktek monopoli, insfrastruktur penyiaran TVRI sudah berusia tua, dan kurangnya kemampuan kompetensi SDM yang dimiliki TVRI. Kepastian hitungan peta alokasi frekuensi di setiap wilayah siar, digital deviden yang diperoleh, dan prospek lembaga penyiaran, harus menjadi dasar utama dalam menentukan model migrasi digital di Indonesia. Bisa jadi kita memiliki model migrasi yang khas Indonesia. DPR bersama Pemerintah, harus segera membahas RUU Penyiaran agar kepentingan masyarakat, bangsa, dan negara Indonesia terkait digitalisasi penyiaran benar-benar dapat terwujud.

Kata Kunci: Perdebatan Kepentingan; Kebijakan Digitalisasi Penyiaran; RUU Penyiaran.
\end{abstract}

\title{
Latar Belakang
}


Digitalisasi Penyiaran di Indonesia telah menjadi tantangan dan dinamika yang menarik pemangku kepentingan. Berbagai kajian dan diskusi mengemuka bahwa era digitalisasi siaran televisi tak mungkin dihindari dari percaturan global. Sementara, di Indonesia masih memerlukan pemetaan yang serius tentang implementasi dan infrastruktur siaran saat ini yang mayoritas masih berbasis analog dan kemudian melakukan migrasi ke digital ${ }^{1}$.

Artinya, kebijakan digitalisasi penyiaran harus diatur dalam UU Penyiaran yang baru sebagai pengganti atas UU Nomor 32 Tahun 2002 tentang Penyiaran yang masih melaksanakan penyiaran dalam termonologi penyiaran analog. Materi digitalisasi penyiaran, telah masuk dalam penggantian UU Penyiaran untuk dirumuskan dan dibahas oleh anggota DPR periode 2009 2014. Namun, pada periode ini pembahasan RUU Penyiaran tidak dapat selesai dan hanya berhasil membahas sampai dengan urutan Daftar Inventarisasi Masalah (DIM) ke 40 dari 865 DIM yang ada di RUU tentang Penyiaran. Bahkan bab mengenai digitalisasi penyiaran belum sempat dibahas oleh DPR bersama Pemerintah.

DPR periode 2014 - 2019 kembali memasukan penggantian UU Penyiaran dalam Program Legislasi Nasional (Prolegnas) 2014 - 2019 dan dijadikan prioritas rancangan undang-undang setiap tahunnya. Posisi terakhir RUU tentang Penyiaran telah diputuskan oleh Komisi I DPR RI sebagai pengusul atas rancangan undang-undang tersebut dan mengajukannya ke Badan Legislasi (Baleg) DPR untuk dilakukan harmonisasi. Namun sampai dengan berakhirnya DPR periode ini, Baleg belum memutuskan hasil harmonisasi

1 Suwandi Sumartias dalam Ahmad Budiman, Kesiapan Lembaga Penyiaran Melaksanakan Digitalisasi Penyiaran, (Jakarta: Balai Pustaka, 2016), vii. atas RUU tentang Penyiaran yang di dalamnya juga mengatur permasalahan digitalisasi penyiaran.

\section{Rumusan Masalah}

Kebijakan mengenai digitalisasi penyiaran yang menjadi salah satu bidang masalah dalam RUU tentang Penyiaran, begitu lama harus melalui waktu perumusannya. Perumusan kebijakan digitalisasi penyiaran harus berhadapan dengan berbagai kepentingan yang pada akhirnya menimbulkan perdebatan dalam perumusannya. Kepentingan tersebut berasal dari berbagai pemangku kepentingan yang terkait dengan penyiaran di Indonesia.

Sejak awal perumusan kebijakaan digitalisasi penyiaran di Indonesia, Pemerintah memiliki kepentingan untuk mematangkan kebijakan ini dalam tataran undang-undang. Pemerintah mendasari kepentingannya atas argumentasi waktu penetapan analog switch off yang apabila tidak dilakukan migrasinya ke penyiaran digital, dampaknya masyarakat tidak akan dapat menyaksikan siaran televisi lagi.

Bagi DPR, kebijakan digitalisasi penyiaran hanyalah merupakan salah satu masalah yang perlu rumuskan disamping permasalahan lain terkait dengan masalah penyiaran di Indonesia. Sedangkan bagi lembaga penyiaran, kepentingannya terkait dengan kesiapan infrastruktur penyiaran dan program siaran yang akan mengisi kanal digital.

Namun masalahnya, perumusan dan pembahasan kebijakan digitalisasi penyiaran yang menjadi salah satu materi dalam penggantian UU Penyiaran, begitu lama penyelesaiannya. Sejak DPR periode 2009-2014 hingga DPR periode 2014-2019 berakhir, kebijakan digitalisasi penyiaran di Indonesia belum bisa ditetapkan. Realitanya, perumusan kebijakan digitalisasi penyiaran 
harus melalui perdebatan kepentingan. Hal inilah yang melandasi penelitian ini, sehingga permasalahan dalam penelitian ini, yaitu: Bagaimana perdebatan kepentingan dalam perumusan kebijakan digitalisasi penyiaran oleh DPR periode 2009-2014? Dan, bagaimana perdebatan kepentingan dalam perumusan kebijakan digitalisasi penyiaran oleh DPR periode 2014-2019?

Hal ini dimungkikan terjadi akibat adanya perbedaan nilai dalam memandang urgensi perlunya mengatur digitalisasi penyiaran di Indonesia. Untuk itu pertanyaan penelitian yang diajukan yaitu bagaimana kontestasi perdebatan kepentingan yang terjadi dalam merumuskan kebijakan tentang digitalisasi penyiaran di Indonesia?

\section{Tujuan dan Kegunaan Penelitian}

Penelitian ini bertujuan untuk mendeskripsikan pertanyaan penelitian mengenai kontestasi perdebatan kepentingan yang terjadi dalam merumuskan kebijakan tentang digitalisasi penyiaran di Indonesia. Sedangkankegunaanteoritisdalam penelitian ini yaitu menunjukkan model migrasi yang sesuai dengan kebutuhan penyiaran di Indonesia. Selanjutnya kegunaan praktis dari penelitian ini adalah memberikan masukan kepada DPR dalam membantu memetakan masalah dan kepentingan dalam perumusan kebijakan digitalisasi penyiaran di Indonesia yang menjadi salah satu masalah dalam penggantian UU Penyiaran.

\section{Kerangka Teori}

Penyiaran digital adalah suatu migrasi teknologi yang dilakukan terutama dalam dunia penyiaran di mana perangkat analog yang sekarang masih banyak dipergunakan dalam waktu dekat sudah mendekati akhir dan tak lagi dipergunakan baik secara nasional maupun skala global. Penyiaran digital akan memberikan kemungkinan lebih banyak kanal (channel) yang tersedia 6 kali lipat dari yang sekarang ada dan memungkinkan untuk lebih banyak siaran dilakukan. Paling tidak, itulah rumusan di atas kertasnya ${ }^{2}$.

Konsekuensi dari digitalisasi yang mendorong kovergensi menurut Bores sebagaimana dikutip dari Ary Shariar (ed) adalah sebagai berikut: ${ }^{3}$

a. Kompresi; pesatnya perkembangan teknik kompresi memungkinkan representasi yang lebih hemat untuk multimedia data.

b. Biaya; efesiensi yang diperoleh dari kompresi adalah penghematan biaya infrastruktur jaringan, baik pada media penyimpanan maupun media transmisi. Penghematan sumber daya sangatlah berperan pada transmisi menggunakan media gelombang radio dikarenakan keterbatasan frekuensi.

c. Fleksibilitas jaringan; pengembangan protokol jaringan yang platformindependence, memungkinkan pengiriman dan pengalihan data multimedia lintas infrastruktur dari industri yang berbeda dan dukungan mobilitas dan layanan yang lebih personal untuk pengguna jaringan.

Pengelolaan multipleksing di media televisi, memerlukan perlakukan yang lebih ketimbang di media radio. Hal ini disebabkan digitalisasi di media televisi adalah merubah semua pola yang selama ini dilakukan melalui sistem analog. Hal lainnya disebabkan oleh karakteristik pengelolaan media televisi yaitu: ${ }^{4}$

2 Ignatius Haryanto, Jurnalisme Era Digital Tantangan Industri Media Abad 21, (Jakarta: Penerbit PT Kompas, 2014), 188.

3 Ary Shariar (ed), Kajian Konvergensi Teknologi Informasi Komunikasi, (Jakarta: BPPT, 2011), 28-29.

4 Askurifai Baksin, Jurnalistik televisi Teori dan Praktek, (Bandung: Penerbit Simbiosis Rekatama Media, 2013), 40 
a. Industri padat modal. Untuk mendirikan dan menghidupkan indsutri ini dibutuhkan ratusan miliar rupiah. Bahkan biaya operasional stasiun televisi per tahunnya bisa mencapai sedikitnya Rp. 150 milyar.

b. Bukan bisnis yang cepat menghasilkan (non quick yielding). Industri penyiaran membutuhkan waktu bertahun-tahun untuk membuat dirinya mandiri secara finansial.

c. Industri dengan entry barriers yang tinggi. Deregulasi perizinan yang luar biasa ketat dan birokratis, menjadikan industri ini sering disebut sebagai industri yang bercirikan entry barriers yang tinggi.

d. Industri yang pasarnya cepat berkembang. Dibandingkan dengan media massa cetak yang pasarnya realtif lambat berkembang, maka pasar industri televisi lebih cepat berkembang. Hal ini dapat dilihat dari besarnya animo pemasang iklan yang menganggap televisi sebagai media utama untuk mengiklankan produknya.

Mengingat penyiaran merupakan industri padat modal, maka industri penyiaran sangat berkepentingan dalam perumusahan kebijakan digitalisasi penyiaran. Kontestasi kepentingan di bidang penyiaran pertama kali dikemukakan oleh Douglas Kellner yaitu kekuasaan pemilik modal televisi di Amerika Serikat sangat besar pengaruhnya terhadap layar televisi. kontestasi akan terus berlangsung ketika demokrasi politik masih kuat dan memungkinkan terjadinya pergantian penguasa 5 . Dalam kaitannya dengan perumusan kebijakan, pemilik modal masuk dalam kelompok kepentingan. Almond dan Powell, membagi kelompok

5 Douglas Kellner, Television and the Crisis of Democracy. Boulder, (Colorado: Westview Press, Inc, 1990) 60. kepentingan menjadi 4 jenis yang salah satunya adalah kelompok assosiasional. yaitu kelompok yang memiliki organisasi yang bersifat formal, dan terorganisir secara baik, dengan keanggotaan yang resmi atau bersifat formal pula. Kelompok assosiasional beranggotakan orang-orang yang berasal dari satu profesi yang sama, dengan tujuan spesifik untuk mewakili kepentingan anggotanya atas bidang-bidang tertentu yang menjadi fokusnya ${ }^{6}$.

Kelompok kepentingan menyampaikan aspirasinya dalam proses perumusan kebijakan. Menurut Jordan and Malanoey dalam Maiwan, menyampaikan dua langkah penyampaian aspirasi yang salah satunya yaitu kelompok kepentingan langsung menyampaikan aspirasi yang sudah diartikulasikan kepada pemerintah. Proses ini biasanya didahului oleh adanya perdebatan ataupun polemik yang luas dalam masyarakat, khususnya melalui media massa. Terkadang sejumlah anggota kelompok kepentingan sengaja "meledakkan" satu isu tertentu ke media massa agar menjadi perhatian umum, sehingga pemerintah turut mengambil perhatian. Mekanisme ini ditempuh jika sistem politik tidak berlangsung secara terbuka dan partai-partai politik tidak bisa menjalankan fungsi-fungsinya secara maksimal. Tingkat kepercayaan masyarakat terhadap partai politik juga rendah?

\section{Metode Penelitian}

Penelitian ini menggunakan metode kualitatif eksploratif yang tidak terstruktur

6 Disari dari Gabriel A. Almond dan G. Bingham Powell, eds., Comparative Politics Today: A World View: Edisi-5, (New York: Harpes Collins, 1992), 62-65.

7 Mohammad Maiwan. 2016. "Kelompok Kepentingan (Interest Group), Kekuasaan dan Kedudukannya dalam Sistem Politik," Jurnal Ilmiah Mimbar Demokrasi Volume 15, Nomor 2 (April 2016): 83. 
yang didasari pada sampel kecil. Analisis data dilakukan berdasarkan keinginan untuk dapat memberikan pemahaman atas permasalahan yang diungkapkan melalui metode deskriptif, yaitu menjelaskan temuan-temuan dalam bentuk tulisan dan menganalisanya dengan bantuan teori-teori yang ada. ${ }^{8}$

Pendalaman kualitatif yang digunakan dalam penelitian ini menggunakan metode studi kasus yang menurut $\mathrm{K}$ Yin diartikan sebagai suatu inquiry empiris yang menyelidiki fenomena dalam kehidupan nyata, bilamana batas-batas antar fenomena dan konteks tak tampak dengan tegas dan dimana multi sumber dimanfaatkan. Sebagai suatu inquiry studi kasus tidak harus dilakukan dalam waktu yang lama dan tidak pula tergantung pada data etnografi atau observasi partisipan. Peneliti bisa saja melakukan studi kasus yang valid dan berkualitas tinggi tanpa meninggalkan kepustakaan, tergantung pada topik yang akan diselidiki 9 .

Penelitian kualitatif studi kasus dipilih untuk mampu mendeskrpsikan kontestasi perdebatan kepentingan yang terjadi dalam merumuskan kebijakan tentang digitalisasi penyiaran yang pembahasannya dilakukan pada DPR periode 2009-2014 dan DPR periode 2014-2019. Perdebatan kepetingan pada perumusan kebijakan digitalisasi penyiaran pada DPR periode 2009-2014 memiliki perbedaan dengan perdebatan kepentingan pada DPR periode 2014 2019. Penelitian ini melihat secara utuh perbedaan kepentingan dari dua periode DPR tersebut. Hal ini yang menyebabkan penelitian ini berbeda dengan penelitian lainnya, karena mengungkap secara jelas perbedaan perdebatan kepentingan

8 Naresh Maholtra, Basic Marketing Research: Applications to Contemporary Issues, $5^{\text {th }} \mathrm{Ed}$, (London: Prentice Hall, 2002), 331-354.

9 Robert K. Yin, Studi Kasus: Desain $E$ Metode, (Jakarta: Rajawali Pers, 2008), 18. perumusan kebijakan digitalisasi penyiaran dari dua periode DPR tersebut. Sedangkan penelitian lain pada umumnya tidak mampu untuk mengungkap perdebatan kepentingan secara lebih mendalam.

Teknik pengumpulan data yang dilakukan dalam penelitian ini yaitu melalui observasi yang berguna untuk menjelaskan, memberikan dan merinci gejala yang terjadi. Ada berbagai cara untuk mengklasifikasikan metode observasi. Kita dapat membaginya berdasarkan keterlibatan peneliti dalam saran penelitian dan memperoleh observasi peserta (participant observation) atau observasi nonpeserta (nonparticipant observation) atau berdasarkan sejauhmana peneliti melakukan "intervensi" terhadap objek yang ditelitinya ${ }^{10}$.

Penelitian ini dilakukan pada perumusan dan pembahasan RUU Penyiaran di DPR periode 2009-2014 dan perumusan RUU Penyiaran di DPR periode 2014-2019. Pada penelitian ini, penulis melakukan teknik pengumpulan data melalui observasi berperanserta, karena pada saat perumusan, pembahasan, dan perumusan RUU Penyiaran, penulis ikut serta di dalamnya.

\section{DPR Periode 2009-2014}

Seluruh fraksi dalam panja RUU Penyiaran DPR periode 2009-2014 sepakat menyampaikan pandangan tentang perlunya payung hukum bagi terselenggaranya digitalisasi penyiaran di Indonesia. Hal ini didasari regulasi yang ada, tidak mengatur digitalisasi penyiaran dari pelaksanaan penyiaran Indonesia. Semua fraksi sepakat bahwa Indonesia harus menetapkan batas akhir penghentian siaran analog (analog switch off(ASO), apabila akan dilakukannya migrasi dari penyiaran analog ke penyiaran digital. Bahwa masyarakat di Indonesia tidak

10 Jalaludin Rakhmat, Metode Penelitian Komunikasi, (Bandung: Remadja Rosdakarya), 2004, 85. 
akan dapat lagi menerima siaran televisi, apabila penyiaran di Indonesia masih diselenggarakan secara analog dan belum bermigrasi ke penyiaran digital. Untuk itu Komisi I menyertakan kelompok pakar pendamping ${ }^{11}$ yang bertugas menyusun RUU tentang Penyiaran yang di dalamnya juga memuat rumusan digitalisasi penyiaran.

Secara sederhana perdebatan kepentingan kebijakan digitalisasi penyiaran, pada DPR periode 2009-2014 sebagaimana bagan berikut ini:

Pada saat Komisi I DPR mulai memberikan penugasannya kepada kelompok pakar pendamping untuk menyusun penggantian

11 Rapat Intern Panja RUU Penyiaran pada tanggal 16 Januari 2012, memutuskan Komisi I DPR RI membentuk dan melibatkan Tim Pakar Pendamping yang terdiri dari kalangan akademisi serta praktisi di bidang penyiaran guna mendapakan saran dan masukan secara lebih komprehensif, yakni Ishadi SK, Ade Armando, Sasa Djuarsa Sendjaja, Amir Effendi Siregar, Paulus Widiyanto serta Sukarno Abdulrachman. Dalam perkembangan berikutnya, ditambahkan satu nama yakni Parni Hardi. Langkah berikutnya, Tim pakar pendamping bekerjasama dengan Tim Asistensi Sekjen DPR RI menyiapkan draft RUU Revisi terhadap UU Penyiaran.

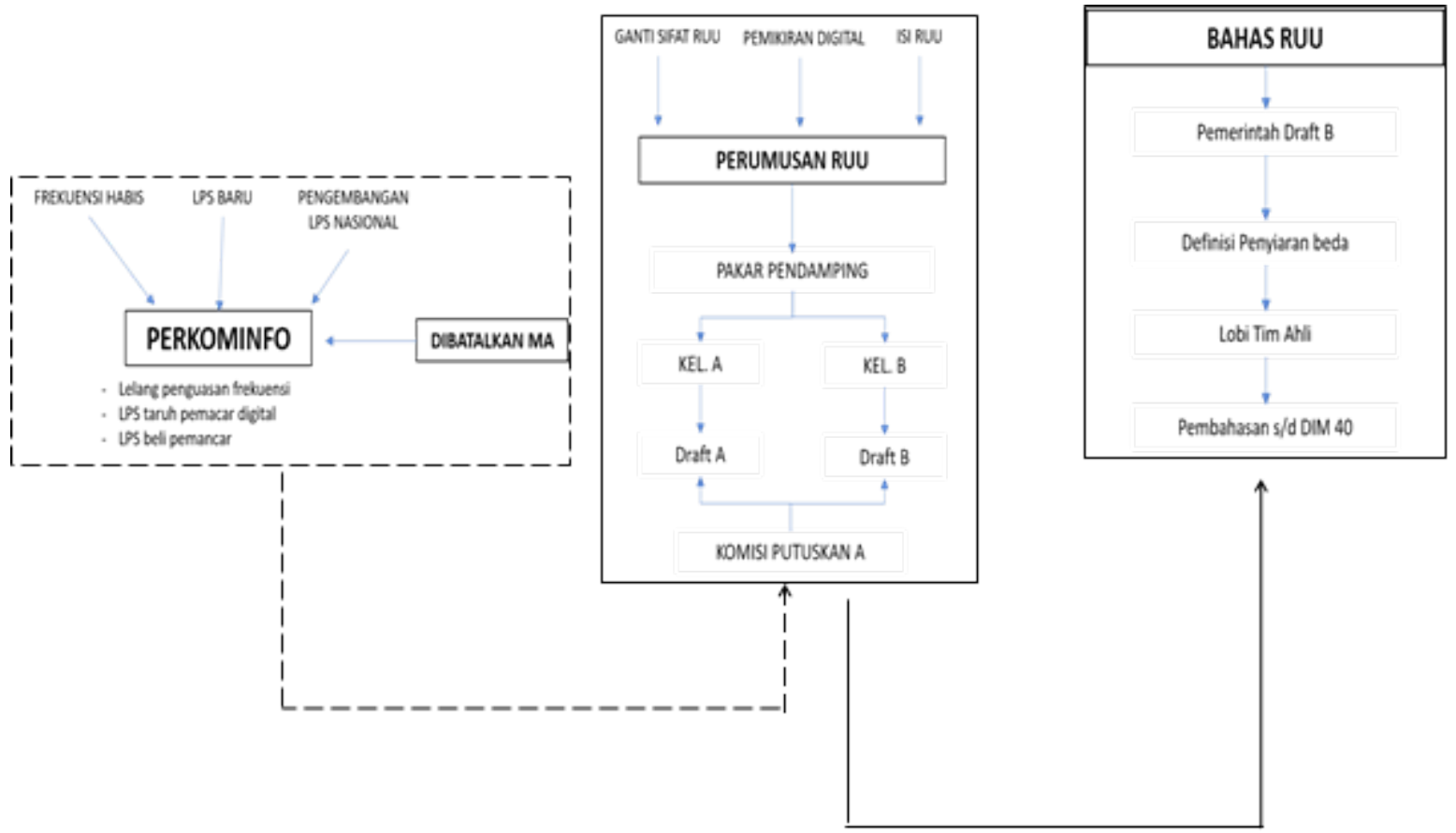

UU Penyiaran, Pemerintah saat itu melalui Kementerian komunikasi dan informatika (Kemkominfo) mengeluarkan kebijakan peraturan menteri yang memberikan arah baru dalam pengelolaan penyiaran digital, melalui Peraturan Menteri Kominfo (Permenkominfo) Nomor 22 Tahun 2011 tentang Penyelenggaraan Penyiaran Televisi Digital Teresterial Penerimaan Tetap Tidak Berbayar. Alasan yang disampaikan pemerintah saat itu yaitu sudah habisnya alokasi frekuensi penyiaran yang digunakan untuk penyiaran analog. Selain itu pemerintah menilai keberadaan lembaga penyiaran swasta baru sudah banyak dan tidak dapat memiliki ijin penyelenggaraan penyiaran (IPP) karena belum melaksanakan uji coba siaran. Pemerintah saat itu juga beranggapan, penataan kehidupan lembaga penyiaran khususnya lembaga penyiaran swasta (LPS) sangat sulit untuk berkembang.

Dampak dari dikeluarkannya kebijakan ini yaitu LPS swasta nasional ikut serta dalam kegiatan lelang penyelenggaraan multipleksing di setiap wilayah siar. Untuk

\section{Bagan 1. Perdebatan Kepentingan Kebijakan Digitalisasi Penyiaran pada DPR Periode 2009-2014}


bisa mengikuti dan memenangkan kebijakan lelang dimaksud, LPS harus menempatkan pemancar digital atau membeli infrastruktur pemancar digital untuk ditempatkan pada wilayah siar dimaksud. Namun permenkominfo akhirnya dibatalkan oleh Mahkamah Agung karena kebijakan digitalisasi penyiaran tidak diamanatkan dalam UU Nomor 32 Tahun 2002 tentang Penyiaran.

Lahirnya permenkominfo, investasi yang telah dilakukan LPS dan dibatalkannya permenkominfo tidak banyak berpengaruh pada perdebatan kepentingan fraksi-fraksi di Komisi IDPR. Bahkan, pada umumnya fraksi menilai keadaan ini sebagai konsekuensi yang harus ditanggung pemerintah karena menghadirkan regulasi yang tidak memiliki "cantolan" regulasi di atasnya.

Perdebatan kepentingan yang terjadi pada kelompok pakar pendamping, ternyata memiliki pengaruh pada perdebatan kepentingan yang terjadi antara DPR dengan Pemerintah. Perdebatan justru menyebabkan dihasilkan dua draft RUU Penyiaran. Hal ini tentunya tidak sesuai dengan keinginan Panja RUU Penyiaran yang mengharapkan dihasilkannya satu naskah rancangan undang-undang yang bisa diajukan oleh Komisi I DPR sebagai rancangan undang-undang usul inisiatif DPR.

Usulan kebijakan digitalisasi penyiaran menyaji terbelah atas dua alternatif yaitu alternatif I yang diajukan oleh Ade Armando, Paulus Widiyanto, Amir Effendy Siregar, dan Parni Hadi. Sedangkan alternatif II diajukan oleh Ishadi SK, Soekarno Abdulrachman dan Sasa Djuarsa Sendjaja. Perbedaan tersebut sebagaimana dideskripsikan dalam tabel berikut ini:

Tabel 1. Perbandingan Draft Kebijakan Digitalisasi Penyiaran Versi Kelompok Pakar Pendamping Panja RUU Penyiaran Komisi I DPR

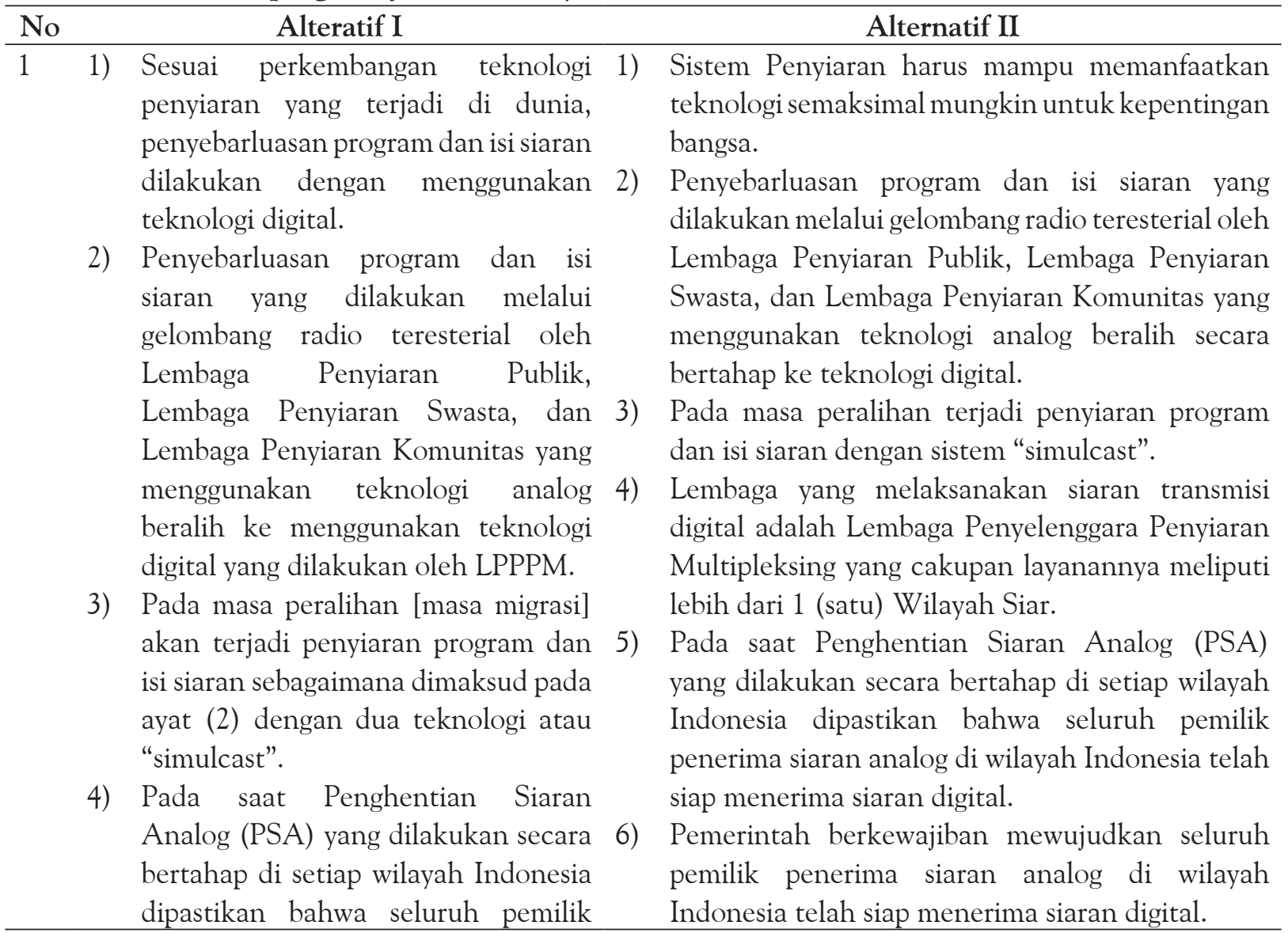




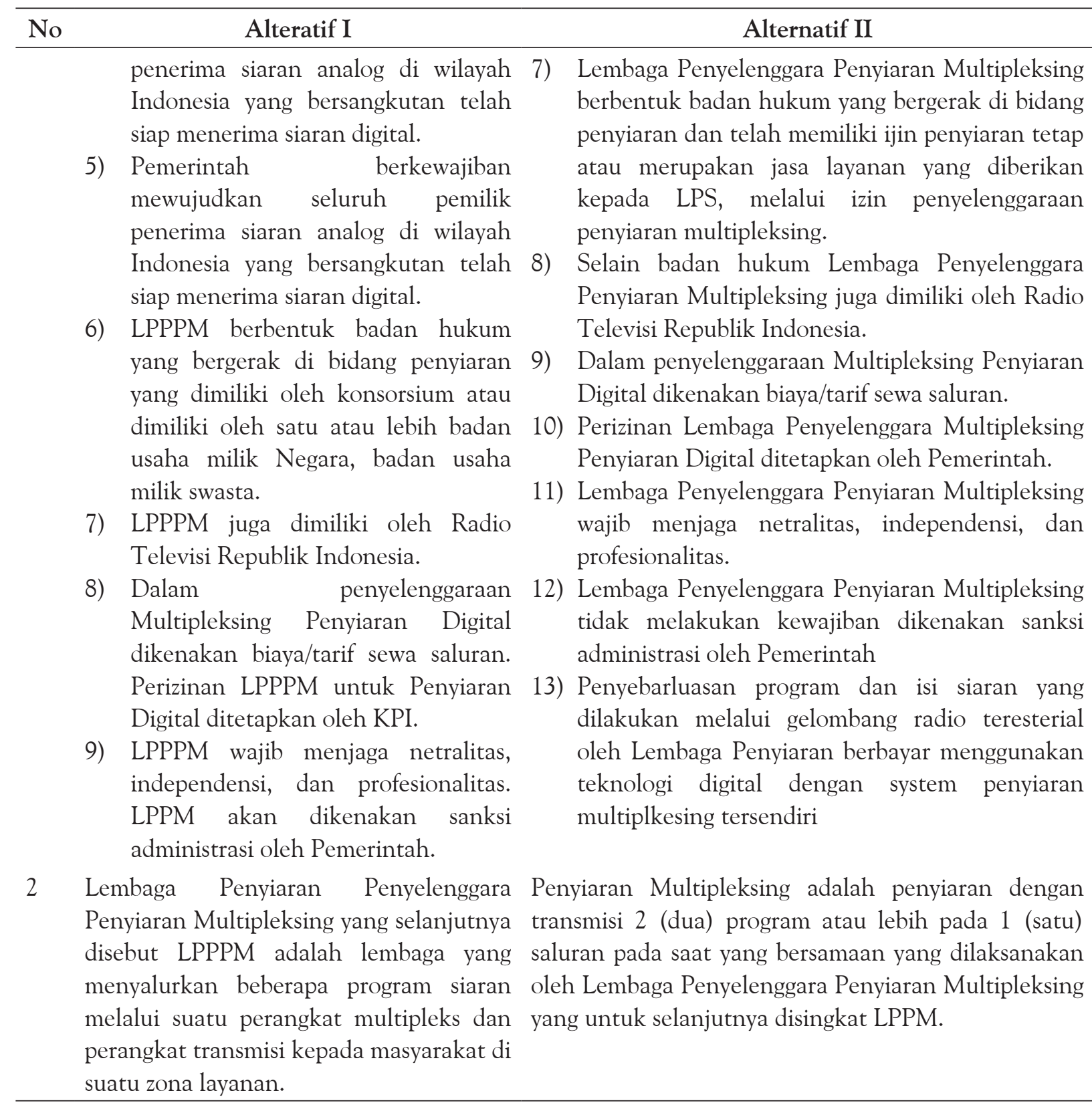

Sumber: Disari dari materi Rapat Panja RUU Penyiaran, 28 Mei 2012.

Perbedaan mendasar dari kedua alternatif ini yaitu pada siapa yang dapat menyelenggarakan penyiaran digital di Indonesia. Alternatif I menekankan penyelenggaraan digitalisasi penyiaran dilakukan oleh Lembaga Penyiaran Penyelenggara Penyiaran Multipleksing (LPPPM) yang berbentuk badan hukum yang bergerak di bidang penyiaran yang dimiliki oleh konsorsium atau dimiliki oleh satu atau lebih badan usaha milik Negara, badan usaha milik swasta, serta oleh Radio Televisi Republik Indonesia (RTRI).
Sedangkan alternatif II menekankan penyelenggaraan digitalisasi penyiaran dilakukan oleh Lembaga Penyiaran Penyelenggara Multipleksing (LPPM) yang berbentuk badan hukum yang bergerak di bidang penyiaran dan telah memiliki ijin penyiaran tetap atau merupakan jasa layanan yang diberikan kepada LPS dan RTRI melalui izin penyelenggaraan penyiaran multipleksing. Komisi I akhirnya memutuskan menerima dan menajukan draft alternatif I untuk dijadikan usul isiatif DPR. Draft alternatif II justru digunakan 
oleh Pemerintah saat itu sebagai dasar dalam menyusun DIM RUU Penyiaran.

Pada penjelasan pengantar DIM yang disampaikan Pemerintah, Menteri Komunikasi dan Informatika juga menjelaskan mengapa Permenkominfo tersebut lebih dahulu dihasilkan dari pada materi perubahan UU Penyiaran. Pemerintah beralasan perlu segera dilakukan penataan digitalisasi, agar Indonesia tidak mengalami proses penghentian analog seketika (ASO). Selain itu karena sudah ada pemenang lelang dari lembaga penyiaran yang telah berinvestasi dan berhak sebagai penyelenggara multipleksing ${ }^{12}$.

Pada rapat kerja pembahasan RUU Penyiaran antara Komisi I DPR dengan Pemerintah, Ketua rapat, menawarkan agar metode pembahasan DIM dilakukan melalui metode pembahasan kluster bidang masalah. Alasannya, DIM yang akan diselesaikan sangat banyak dan untuk mempercepat pembahasan substansinya dapat dilakukan dengan cara kluster atas substansi yang sama. Hal ini akan memudahkan pembahasan dan menyetujui substansi, sehingga dapat diteruskan ke forum rapat tim perumus.

Semua fraksi di Komisi I DPR menyetujui metode yang ditawarkan ketua rapat. Namun pemerintah keberatan dengan penggunaan metode pembahasan kluster pada DIM RUU Penyiaran. Pemerintah meminta pembahasan tetap dilakukan secara sistematis dari mulai nomor 1 sampai dengan selesai. Pemerintah berasalan, pembahasan yang sistematis akan membantu memahami pokok masalah secara tepat dan sistematis. Hal ini disebabkan setiap materi dalam setiap pasalnya, pasti memiliki keterkaitan dengan pasal yang lainnya. Raker sempat

12 Disari dari Risalah Rapat Kerja Pembahasan RUU Penyiaran antara Komisi I dengan Pemerintah dengan agenda penjelasan Pemerintah atas materi DIM RUU Penyiaran yang disampaikan Pemerintah di skors untuk membahas masalah ini dalam forum loby. Setelah skors dicabut, ketua rapat menyampaikan hasil loby yaitu metode pembahasan RUU Penyiaran tetap dilakukan secara sistematis dari mulai DIM nomor 1 dan seterusnya.

Perdebatan kepentingan justru berasal dari fraksi-fraksi yang memiliki perbedaan dalam definisi penyiaran. Perbedaan itu berasal dari keinginan untuk menghilangkan frasa tertentu dalam definisi penyiaran. Beberapa frasa yang ingin dihilangkan dalam definisi penyiaran yaitu:

1. Frasa "pengaliran" karena makna kegiatanya sudah termuat dalam kegiatan penyaluran yang bentuk konkrit kegiatannya dilakukan dengan menggunakan spektrum frekuensi radio melalui kabel.

2. Frasa "pipa aliran" karena penyiaran hanya mengenal sarana pemancaran dan sarana transmisi yang digunakan untuk kegiatan penyiaran.

3. Frasa "sarana transmisi" karena maknanya sama dengan sarana pemancaran.

4. Frasa "media lainnya" karena membuat aktivitas penyiaran menjadi tidak jelas batasan yang diperbolehkan dalam penyebarluasan siaran. Walaupun beberapa fraksi menyatakan hal ini dimaksudkan mengantisipasi kemungkinan perkembangan teknologi di bidang penyiaran.

Perbedaan pandangan antara fraksifraksi dan pemerintah menyebabkan DIM untuk nomor ini diputuskan untuk dipending yang akan dibahas pada rapat kerja berikutnya. Namun masa tugas DPR periode 2009-2014 sudah berakhir dan raker pembahasan RUU Penyiaran antara DPR bersama Pemerintah, hanya bisa dilakukan sampai dengan DIM 40 terkait dengan beberapa definisi dalam RUU Penyiaran. 


\section{DPR Periode 2014-2019}

DPR periode 2014-2019 kembali mengagendakan RUU Penyiaran masuk dalam Prolegnas di tahun 2014. Pada keanggotaan DPR periode berikutnya, RUU Penyiaran dirumuskan kembali oleh Komisi I DPR. Secara sederhana gambaran perdebatan kepentingan yang terjadi terkait pembahasan regulasi digitalisasi penyiaran di Indonesia, tergambar pada bagan berikut ini.

Ketua Komisi I (Mahfudz Sidiq/FPKS) menugaskan kepada tim asistensi untuk mempersiapkan materi draft RUU Penyiaran berikut naskah akademiknya. Membangun regulasi penyiaran yang di dalamnya memuat rancangan kebijakan mengenai digitalisasi penyiaran, harus di susun pada kerangka regulasi yang sistematis dan menjadi dasar dalam penyusunan redaksional pasalnya. Kerangka regulasinya memuat tentang:

1. Negara dalam konteks penyiaran harus disebutkan dengan jelas dalam kaitannya dengan frekuensi penyiaran dan dalam kaitannya dengan konten siaran. Pada bagian konsideran menimbang, harus dengan jelas mengungkapkan posisi negara sebagaimana termuat dalam konstitusi UUD 1945 dalam kaitannya dengan spektrum frekuensi radio yang bersifat terbatas dan dalam kaitannya dengan kebebasan setiap warga negara untuk mendapatkan informasi.

2. Definisi penyiaran sudah harus mencerminkan arah penyiaran Indonesia menuju era penyiaran digital. Untuk itu beberapa hal mendasar dari definisi penyiaran harus mencerminkan hal terkait dengan sistem penyiaran digital, seperti memancarteruskan dan menyebarkan, sifat siaran satu arah atau interaktif, sarana pemancaran atau pipa aliran, dan/atau sarana transmisi di darat, laut, udara, atau antariksa, serta menggunakan spektrum frekuensi radio. pada definisi penyiaran ini juga perlu dipertegas, digitalisasi penyiaran yang dikembangkan di Indonesia yaitu penyiaran digital terrestrial.

\section{HARMONISASI DI BALEG}

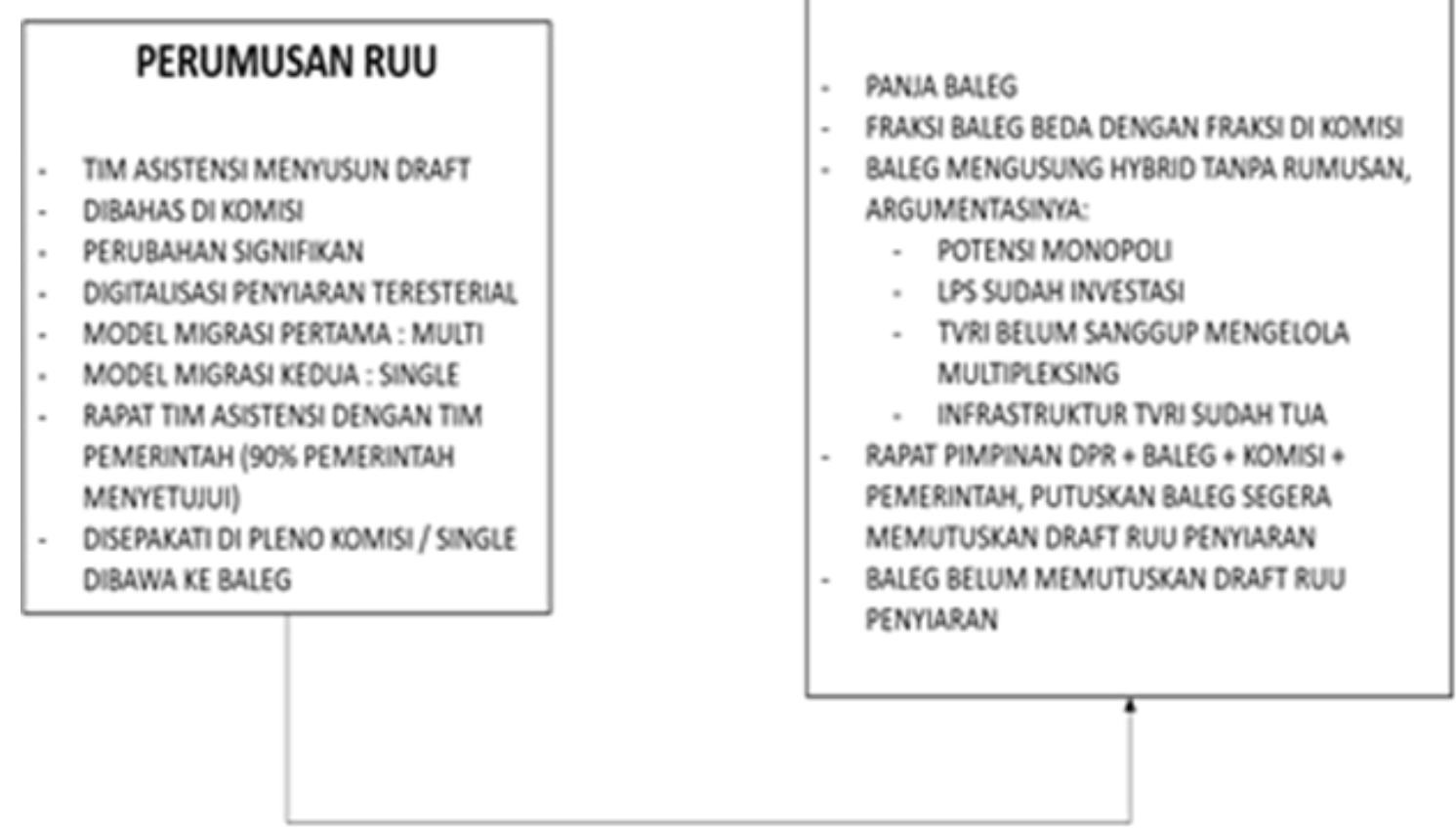

Bagan 2. Perdebatan Kepentingan Kebijakan Digitalisasi Penyiaran pada DPR Periode 2014-2019 
3. Implementasi dari konsideran menimbang, perlu diperkuat pada batang tubuh terkait dengan posisi negara dalam penyiaran. Negara dalam kaitannya dengan pengelolaan, penataan frekuensi di setiap wilayah siar, perijinan dan perpanjangan ijin penyelenggaraan penyiaran, serta pencabutan ijin frekuensi, merupakan domain pemerintah setelah mendapatkan masukan dari Komisi Penyiaran Indonesia (KPI). Sedangkan negara dalam kaitannya dengan menjaga kualitas, pengawasan, perlindungan masyarakat dari materi penyiaran, merupakan kewenangan KPI untuk menanganinya.

Pembahasan untuk merumuskan RUU Penyiaran dilakukan oleh Panja RUU Penyiaran Komisi I dengan sifat rapat tertutup. Khusus pembahasan dalam merumuskan bab mengenai digitalisasi penyiaran, pembahasan dilakukan terakhir setelah seluruh bab dalam RUU Penyiaran telah selesai diputuskan oleh Panja. Hal ini didasari oleh kondisi perdebatan pendapat dari fraksi-fraksi dalam menilai masalah digitalisasi penyiaran dan proses migrasi digital yang paling cocok bagi penyiaran di Indonesia.

Perdebatan fraksi-fraksi terkait dengan seberapa luas pengaturan digitalisasi penyiaran di Indonesia, apakah hanya terbatas pada digitalisasi teresterial atau mencakup juga digitalisasi penyiaran pada ranah internet? Perdebatan kedua terkait dengan bagaimana model migrasi yang paling cocok bagi penyiaran digital di Indonesia. Untuk point ini, pandangan fraksi terbelah atas pendapat yang menyatakan harus negara yang menguasai penyelenggaraan digitalisasi penyiaran di Indonesia, namun ada juga fraksi yang menyatakan penyelenggaraan digitalisasi penyiaran harus dilakukan oleh lembaga penyiaran.
Hal utama yang diputuskan Panja yaitu digitalisasi penyiaran di Indonesia merupakan digitalisasi teresterial ${ }^{13}$. Walaupun di awal keputusan tersebut, beberapa fraksi memberikan simulasi tentang berbagai kemungkinan pengembangan penyiaran di era digital khususnya menggunakan fasilitas internet ${ }^{14}$. Alasan dari diputuskannya digitalisasi teresterial yaitu:

1. Jasa penyiaran yang dikenal dalam penyiaran di Indonesia yaitu jasa penyiaran radio dan televisi, serta tidak termasuk jasa penyiaran internet.

2. Internet dapat digunakan sebagai salah satu bentuk pengembangan usaha dari jasa penyiaran radio dan jasa penyiaran televisi.

3. Internet menggunakan fasilitas frekuensi telekomunikasi yang regulasinya diatur dalam UU Telekomunikasi.

4. Lembaga penyiaran yang akan menerapkan kebijakan digitalisasi penyiaran merupakan lembaga penyiaran dengan jasa penyiaran radio dan jasa penyiarann televisi.

5. Kebutuhan masyarakat untuk mendapatkan materi siaran lebih banyak di dapat melalui jasa penyiaran radio dan jasa penyiaran televisi.

6. Regulator pengawas isi siaran (KPI) adalah lembaga pengawas isi siaran yang dilakukan oleh lembaga penyiaran penyelenggara jasa penyiaran radio dan jasa penyiaran televisi.

Terkait dengan Analog Switch Off (ASO) semua fraksi sepakat untuk memberikan kepastian waktu yang tetap dan dimuat di dalam UU Penyiaran. Fraksi Gerindra menyatakan, "kita ingin ada satu ketetapan tahun yang pasti untuk target analog switch

13 Evita Nusanti (FPDIP) mengusulkan digunaknnya digitalisasi teresterial. Pendapat yang sama diajukan oleh Budi Youyastri (FPAN) dan Sukamta (FPKS).

14 Diusulkan FPG, FPPP dan FPD. 
off. Kalau memang harus kita melakukan itu, maka mestinya ada di pasal-pasal sebelum pasal-pasal awal tentang digitalisasi penyiaran itu. Pasal ini belum kita dengar dan kita berharap ini bisa masuk"15.

Hal senada disampaikan FPDIP yang menyebutkan perlu kepastian waktu dalam menetapkan ASO yang diatur dalam UU Penyiaran. Time frame-nya paling lama 5 tahun, agar Pemerintah memiliki target waktu akhir menetapkan ASO. UndangUndang mewajibkan Pemerintah untuk menyelesaikan $\mathrm{ASO}^{16}$. Sedangkan FPKS setuju dengan pandangan fraksi yang lain, namun tahapan teknis pemberlakukan ASO di setiap wilayah siar bisa diserahkan ke peraturan pemerintah ${ }^{17}$. Beberapa fraksi yang lain justru mengusulkan ASO diatur dalam undang-undang tersendiri.

Keputusan Panja RUU Penyiaran yaitu ASO paling lambat 5 (lima) tahun terhitung sejak diundangkannya undangundang penyiaran. Untuk itu Pemerintah perlu memberikan jaminan ketersediaan frekuensi bagi lembaga penyiaran jasa penyiaran televisi. Selain itu Pemerintah wajib menyusun cetak biru penyelenggaraan Penyiaran dengan teknologi digital jasa Penyiaran televisi yang berisi pertimbangan alokasi frekuensi digital di setiap Wilayah Siar, kesiapan masyarakat, kesiapan penyelenggara Penyiaran, kesiapan produsen perangkat Penyiaran, kesiapan distribusi alat pendukung teknologi digital; dan iklim usaha yang sehat ${ }^{18}$.

Perumusan model migrasi analog ke digital, merupakan materi yang cukup intensif dibahas oleh Panja RUU Penyiaran.

15 Sekretariat Jenderal DPR RI, Risalah Rapat Panja RUU Penyiaran Komisi I DPR RI, tanggal 2-Juli2015

16 Ibid.

17 Ibid.

18 Disari dari Risalah Rapat Panja RUU Penyiaran di Komisi I DPR RI, 19 April 2016.
Pada awal pembahasan perumusan model migrasi, tidak dikenal istilah single mux, multi mux atau hybrid mux. Panja lebih fokus pada perumusan modekl migrasi tersebut. Pada rumusan awal, tim asistensi setelah mendapatkan arahan dari Ketua Komisi I merumuskan model migrasi digital dilakukan oleh penyelenggara digitalisasi penyiaran yang dilaksanakan oleh lembaga penyiaran yang telah memiliki izin penyelenggaraan penyiaran (IPP). Hal ini dimaksudkan menciptakan keadilan kepada semua lembaga penyiaran yang ada, untuk tetap bersiaran dan melaksanakan migrasi dari analog ke digital. Disamping proses migrasi analog ke digital dapat dengan segera terlaksana. Namun dampaknya, digital deviden dari migrasi analog ke digital hampir tidak ada. Dampak lainnya yaitu tidak memberikan kesempatan kepada lembaga penyiaran baru, untuk dapat melakukan uji coba siaran dan menyelenggarakan siarannya.

Panja RUU Penyiaran belum dapat memutuskan model migrasi yang akan digunakan di Indonesia. Panja Penyiaran selanjutnya menugaskan kepada tim asistensi untuk menyusun model migrasi yang hanya dikelola oleh negara dan kemudian di bandingkan dengan model migrasi yang telah diajukan oleh tim asistensi. Pada rapat Panja 1 September 2015, tim asistensi menyampaikan model migrasi yang diserahkan kepada negara selanjutnya dapat dilakukan oleh lembaga penyiaran publik, atau BUMN, atau lembaga baru yang dibentuk, atau kepada pemerintah. Perdebatan fraksi kemudian mengerucut pada pilihan model migrasi yang dilakukan oleh lembaga penyiaran publik atau lembaga penyiaran swasta. Pada rapat ini pula mulai dikenal istilah single mux yang diserahkan kepada negara dan multi mux yang diserahkan kepada banyak lembaga penyiaran. 
Setelah melalui perdebatan panjang, Panja memutuskan model migrasi digital dilakukan oleh lembaga penyiaran publik dan lembaga penyiaran swasta sebagai penyelenggara penyiaran digital. Lembaga penyiaran publik dan lembaga penyiaran swasta dapat mengunakan sendiri kanal digital yang dimilkinya, atau menyewakan kepada lembaga penyiaran lainnya. Bila disewakan kepada lembaga penyiaran lain, maka lembaga penyiaran itu akan berfungsi sebagai penyelenggara multipleksing. Namun demikian, lembaga penyiaran swasta yang mendapatkan kesempatan sebagai penyelenggara mux diwajibkan untuk membayar prosentase keuntungan sebesar $1,75 \%$ yang didapatkannya kepada lembaga penyiaran publik.

Secara keseluruhan draf RUU Penyiaran telah dilaporkan Panja RUU Penyiaran kepada Komisi I DPR pada tanggal 8 Desember 2016. Catatan penting yang disampaikan dalam rapat intern Komisi I saat itu yakni rapat memberikan waktu kepada fraksi-fraksi untuk mempelajari kembali pasal-pasal yang terkait dengan model migrasi dan pengelolaan frekuensi penyiaran, dan akan diputuskan dalam Rapat Intern Komisi I DPR RI berikutnya, guna selanjutnya disampaikan kepada Baleg untuk diharmonisasi ${ }^{19}$.

Menindaklanjuti catatan tersebut, ketua kelompok fraksi di Komisi I DPR melakukan loby tertutup tanpa dihadiri Sekretariat Komisi I dan Tim Asistensi. Hasilnya loby memutuskan kebijakan model migrasi digital, sebagaimana termuat dalam draf RUU Penyiaran per tanggal 6 Februari 2017. Hal penting terkait dengan model migrasi digital yaitu model migrasi dari penyiaran analog ke digital adalah multiplekser tunggal. Frekuensi

19 Sekretariat Komisi I DPR RI, Laporan Kronologis Perjalanan Perumusan RUU Penyiaran 2010-2016. dikuasai oleh negara dan pengelolaannya dilakukan oleh Pemerintah. Untuk itu lembaga penyiaran publik bertindak sebagai penyelenggara multiplekser tunggal.

Panja juga mewajibkan kepada Pemerintah untuk menetapkan tata cara migrasi teknologi analog ke digital yang terdiri dari:

a. penentuan batas akhir penggunaan teknologi analog per-wilayah siar;

b. penataan alokasi frekuensi dengan persetujuan Dewan Perwakilan Rakyat Republik Indonesia;

c. penetapan standar pelayanan Siaran digital;

d. pengaturan batas akhir produksi dan distribusi televisi dengan teknologi analog; dan

e. penetapan tarif sewa infrastruktur Penyiaran digital.

LPP dalam menjalankan perannya sebagai penyelenggara multipleksing tunggal memiliki kewajiban untuk memberikan perlakuan yang sama kepada semua lembaga penyiaran disetiap wilayah siar, menyewakan saluran digital sesuai dengan penataan alokasi frekuensi, dan menjamin kualitas penyajian siaran digital kepada lembaga penyiaran sesuai dengan standar pelayanan siaran digital. LPP dapat memberikan kesempatan kepada lembaga penyiaran yang akan melakukan pengembangan saluran digital di satu wilayah siar. Untuk semua kewajiban tersebut, LPP wajib melaporkan kinerjanya secara periodik kepada Dewan Perwakilan Rakyat Republik Indonesia.

Komisi I telah memutuskan RUU Penyiaran dan menyampaikannya ke Baleg untuk dilakukan harmonisasi. Mengawali tahapan kegiatan harmonisasi, Baleg memanggil semua pemangku kepentingan terkait penyiaran. Tujuannya untuk mendapatkan bahan masukan terkait dengan permasalahan penyiaran dan 
drafting RUU Penyiaran. Hasil kerja Panja Hamonisasi RUU Penyiaran di Baleg, kemudian disampaikan kepada Komisi I DPR sebagai pengusul dalam forum rapat panja yang bersifat tertutup. Semua materi yang diharmonisasi Baleg telah disepakati oleh Komisi I DPR, kecuali materi yang terkait dengan model migrasi analog ke digital.

Fraksi-fraksi di Baleg menilai, model migrasi dengan menyerahkan kepada LPP sebagai penyelenggara multipleksing tunggal (single mux) sangat tidak tepat ${ }^{20}$. Hal utama yang disampaikan oleh Fraksi di Baleg yaitu: - multipleksing tunggal itu memiliki potensi monopoli penguasaan frekuensi penyiaran yang sangat besar kepada LPP,

- lembaga penyiaran swasta (LPS) telah melakukan investasi teknologi digital di setiap wilayah siar,

- TVRI dinilai belum sanggup untuk menjalankan perannya sebagai penyelenggara multipleksing disebabkan kemampuan kompetensi sumber daya manusianya yang terbatas dan sudah berusia tua, dan

- Kemampuan infrastruktur TVRI yang sudah tua dan masih banyak yang bersifat analog.

Argumentasi inilah yang menyebabkan Baleg DPR tidak menyetujui sistem migrasi analog ke digital menggunakan metode single mux. Baleg DPR mengusulkan model migrasi analog ke digital dilakukan dengan metode hybrid mux (walaupun saat itu belum ada rumusan kebijakan mengenai hybrid mux). Argumentasi dari usulan itu, karena LPS sudah lebih dahulu melakukan investasi infrastruktur digital, memiliki kemampuan pemancar dengan kualitas yang baik, dan didukung oleh kemampuan kompetensi SDM yang muda dan handal.

20 Pandangan ini disampaikan FPDIP dan FPG di Baleg DPR
Menanggapi hal ini, komisi I DPR tetap mempertahankan argumentasinya pada sistem pengelolaan multipleksing tunggal (single mux). Kondisi ini menyebabkan rapat pleno Panja Harmonisasi RUU Penyiaran di Baleg DPR tidak dapat memutuskan model migrasi dimaksud. Panja menetapkan akan memberikan keputusan model migrasi setelah memasui masa sidang berikutnya. Namun sejak rapat panja tanggal 20 September 2017, tidak pernah lagi ada rapat di Baleg DPR membahas masalah ini. Hingga akhir masa jabatan DPR periode 20142019, Baleg tidak berhasil memutuskan harmonisasi RUU Penyiaran.

\section{Analisis}

Lamanya perumusan dan pembahasan kebijakan digitalisasi penyiaran yang merupakan salah satu materi dari sekian banyak materi mengenai kebijakan penyiaran di Indonesia, menunjukkan materi ini memang sangat sarat kepentingan. Perdebatan dalam rapat di internal Komisi I, pembahasan dengan Pemerintah atau di rapat Panja Baleg, menunjukkan bahwa masalah digitalisasi penyiaran secara substansi sangat terkait dengan substansi penyiaran secara keseluruhan. Selain itu, digitalisasi penyiaran juga terkait dengan eksistensi lembaga penyiaran dalam menyelenggarakan penyiaran.

Perdebatan kepentingan mengenai kebijakan model migrasi di Indonesia, baik yang terjadi pada DPR periode 2009-2014 atau DPR periode 2014-2019, memang secara spesifik merupakan substansi yang didorong oleh lembaga penyiaran. Kepentingan substantif yang didorong oleh lembaga penyiaran (secara khusus oleh lembaga penyiaran swasta) disampaikan kepada DPR sebagai sebuah aspirasi. Pada DPR periode 2009-2014, aspirasi lembaga penyiaran disalurkan melalui pakar 
pendamping yang menghasilkan alternatif $\mathrm{B}$ dan kepada Pemerintah berhadapan dengan DPR yang memperjuangkan aspirasi publik. Sedangkan pada DPR periode 2014-2019, Komisi I yang memperjuangkan aspirasi publik harus berhadapan dengan Baleg yang memperjuangkan aspirasi lembaga penyiaran. Hal ini menunjukkan kepastian hukum mengenai model migrasi penyiaran analog menjadi digital, merupakan tujuan atau kepentingan spesifik yang ingin diperjuangkan mereka.

Sejalan dengan disampaikannya kepentingan lembaga penyiaran kepada Pemerintah atau Baleg, lembaga penyiaran juga menyampaikan isu perdebatan kepentingan ini di media massa agar mendapatkan perhatian dan perdebatan di masyarakat. Hal ini bisa dipastikan untuk menciptakan tekanan kepada Pemerintah atau Baleg untuk mengakomodir kepentingan ini. Walaupun aktivitas loby dari lembaga penyiaran tidak terlihat di masyarakat, namun perdebatan kepentingan yang dibawa oleh Pemerintah dan Baleg, menunjukkan begitu intensifnya loby dari lembaga penyiaran mengenai model migrasi yang sesuai dengan kepentingan mereka.

Memang bisa dipahami, kalau lembaga penyiaran merupakan sebuah industri padat modal. Biaya pendirian dan biaya operasional siaran yang sangat besar, menyebabkan industri lembaga penyiaran memerlukan kepastian penyelenggaraan usaha penyiaran. Selanjutnya upaya untuk mendatangkan keuntungan dari industri ini, tidak dengan waktu yang cepat dapat tercapai. Perlu waktu yang lama untuk dapat mengembalikan keuntungan dari modal usaha lembaga penyiaran.

Industri penyiaran juga harus taat kepada berbagai regulasi yang ketat dan birokratis terutama terkait dengan frekuensi dan siaran. Hal ini bisa dipahami, mengingat industri ini menggunakan frekuensi penyiaran yang merupakan spektrum frekuensi radio yang keberadaannya sangat terbatas. Untuk itu negara memang sangat membatasi dan mengatur penggunaannya.

Masuknya kepentingan industri penyiaran inilah yang menyebabkan perdebatan perumusan, pembahasan dengan perumusan, perumusan dengan tim asistensi, dan tahapan harmonisasi di Baleg, harus melawati perdebatan kepentingan kebijakan digitalisasi penyiaran di Indonesia. Kepentingan lembaga penyiaran untuk menguasai frekuensi penyiaran digital dan dilanjutkan dengan investasi infrastruktur penyiaran dapat dimaklumi, mengingat satu kanal dalam penyiaran digital dapat dibagi atas beberapa kanal yang disesuaikan dengan kebutuhan penggunaan frekuensinya. Satu pemancar digital memang telah dipersiapkan untuk mampu memancarteruskan 8-12 kanal siaran televisi digital.

Keunggulan penyiaran digital ketimbang penyiaran analog juga menjadi daya tarik yang cukup mempengaruhi lembaga penyiaran untuk menguasainya. Secara teknik pola multipleksing menunjukkan konsep jaringan penyiaran dengan jalur interaktifnya. Disini terlihat adanya pemisahan antara jaringan pendistribusian (distribution network) dan jaringan penghantar (delivery network) ke pengguna. Pemisahan jaringan di atas juga menunjukkan opsi bisnis terpisah antara operator jaringan pendistribusian dan jaringan penghantar. Lembaga penyiaran tidak hanya berfungsi sebagai penyelenggara isi siaran, tetapi juga dapat berfungsi sebagai penyelenggara multipleksing dengan keuntungan sewa kanal yang cukup besar.

Sementara itu dari sisi layanan siaran juga memiliki potensi keuntungan yang lebih besar, bila menggunakan penyiaran digital. Layanan penyiaran bisa berbentuk layanan tidak berbayar (free to air tv) yang 
mengandalkan pendapatan dari iklan atau biaya transaksi penggunaan aplikasi interaktif atau berbayar (pay tv) dengan pendapatan dari biaya berlangganan. Selain itu bisa juga disusun mekanisme hybrid di mana layanan dasarnya tidak berbayar namun untuk siaran atau aplikasi khusus dikenakan biaya langganan.

Keuntungan-keuntungan itulah yang menjadikan lembaga penyiaran berani untuk melakukan investasi besar dan berusaha untuk memastikan kebijakan tersebut dilaksanakan sesuai dengan pola bisnis mereka. Hal ini dicirikan dari munculnya perdebatan perumusan kebijakan digitalisasi penyiaran terkait dengan siapa yang berhak menjadi penyelenggara multipeksing. Penunjukkan hanya kepada satu lembaga penyiaran, pasti menimbulkan resistensi dari lembaga penyiaran lainnya. Itu sebabnya, argumentasi monopoli akan terjadi bila model migrasinya menggunakan sistem single mux, sangat logis sekali.

Namun sebaliknya, penguasaan frekuensi digital oleh beberapa lembaga penyiaran juga dikhawatirkan dapat menyebabkan timbulnya penguasaan lembaga penyiaran di lokal oleh lembaga penyiaran berskla nasional. Hal ini dapat terjadi bila dapat perjalanannya, lembaga penyiaran lokal tidak sanggup lagi melakukan sewa kanal digital dan tidak seimbangnya pemasukan iklan untuk materi acara yang mereka tayangkan. Artinya, baik single ataupun hybrid sama-sama memiliki potensi monopoli bila tidak jelasnya ukuran penyelenggaraan penyiaran digital.

Ukuran penyelenggaraan penyiaran digital inilah yang dalam konsep kebijakan penyiaran digital, diserahkan kepada Pemerintah untuk menyusun cetak biru penyelenggaraan penyiaran digital. Pemerintah memang wajib untuk menyusun, menyosialisasikan, dan memutakhirkan peta alokasi frekuensi di setiap wilayah siar. Berdasarkan peta alokasi frekuensi, sebetulnya menjadi dasar dari pengelolaan frekuensi di setiap wilayah siar dan secara nasional. Peta alokasi ini akan dapat menentukan berapa jumlah penyelenggara multipleksing di setiap wilayah siar. Bila pilihannya hanya satu penyelenggara multipleksing, maka harus bisa dipastikan semua lembaga penyiaran yang ada di wilayah siar tersebut, dapat menerima layanan penyenggaraan multipleksing. Hal ini sekaligus juga untuk menjawab keraguan akan terjadinya praktek monopoli, bila pilihannya adalah single mux.

Pada cetak biru penyelenggaraan digitalisasi penyiaran, juga perlu memuat besaran tarif yang disesuaikan dengan kondisi kelayakan siaran di setiap wilayah siar dan pemasukan dari iklan. Daerah dengan penduduk yang banyak, pasti berdampak pada besaran tarif sewa kanal karena terkait dengan potensi besarnya jumlah penonton televisi. Artinya, setiap wilayah siar pasti memiliki tarif yang berbeda satu dengan yang lainnya. Hal ini juga menjadi alasan untuk menjawab kekhawatiran akan terjadinya praktek monopoli. Semua pihak tentunya harus patuh akan besaran tarif yang dikeluarkan Pemerintah yang telah disusun berdasarkan perhitungan lengkap dan menyeluruh di setiap wilayah siar.

Melalui cetak biru ini pula, akan mampu diantisipasi perkembangan kebutuhan lebar pita frekuensi digital bagi lembaga penyiaran pada masa-masa berikutnya. Itu sebabnya di dalam cetak biru ini perlu memuat batas akhir penyelenggaraan siaran analog di setiap wilayah siar dan sekaligus sebagai penanda dimulainya siaran digital di Indonesia. Analog Switch Off (ASO) sangat ditentukan dari telah siapnya model migrasi yang akan dilaksanakan oleh lembaga penyiaran. ASO juga menuntut kesiapan 
lembaga penyiaran untuk mempersiapkan infrastruktur dan konten siara digital.

Pokok-pokok materi dalam cetak biru penyelenggaraan penyiaran digital, sebetulnya memberikan gambaran jelas kepada kita semua bahwa kebijakan digitalisasi penyiaran di Indonesia harus disusun berdasarkan kondisi teknis frekuensi digital di setiap wilayah siar. Bahwa kondisi teknis tersebut akan mampu menjawab prasangka akan ada atau tidaknya praktek monopoli pada penerapan digitalisasi penyiaran di Indonesia. Namun memang harus disadari hal-hal teknis terkait dengan pilihan penggunaan jenis penggunaan frekuensi digital, apakah SD, HD, atau UHD tidak akan mungkin masuk dalam rancangan kebijakan besar mengenai penyiaran di Indonesia. Pilihannya diserahkan oleh Pemerintah kepada lembaga penyiaran di setiap wilayah siar, sesuai dengan kebutuhan pengembangan siaran digitalnya dan sesuai dengan kebutuhan bisnis kerjasama penyelenggaraan multipleksing. Pilihan ini juga berdampak pada besarnya tarif yang dikenakan dari lembaga penyiaran yang menggunakannya.

Digitalisasi penyiaran bagi Pemerintah memiliki kepentingan untuk tersedia dan tertatanya frekuensi penyiaran yang lebih baik di setiap wilayah siar. Melalui kebijakan ini frekuensi penyiaran tidak selalui melekat pada lembaga penyiaran. Pada era penyiaran digital, ada lembaga penyiaran yang hanya menyelenggarakan konten siaran, sedangkan pemancarluasan siaran dilakukan melalui kerjasama dengan penyelenggara multipleksing. Itu sebabnya Pemerintah tidak terlalu terjebak pada perdebatan kepentingan single atau hybrid mux. Pemerintah juga tidak terjebak pada perdebatan potensi monopoli oleh lembaga penyiaran kepada lembaga penyiaran lainnya.
Penataan frekuensi penyiaran di era penyiaran digital memberikan kesempatan untuk menguasai sekaligus menata kembali frekuensi penyiaran yang dimiliki lembaga penyiaran selama ini. Dikembalikannya frekuensi analog dan beralihnya menjadi frekuensi digital, menyebabkan Pemerintah memiliki data yang konkrit terkait dengan ketersediaan sisa frekuensi yang telah beralih kepada frekuensi digital. Pemerintah memiliki menguasai dan memiliki data yang lengkap mengenai digital deviden di setiap wilayah siar. Kepentingan ini tentunya sangat berharga bagi Pemerintah dalam menentukan penggunaan frekuensi ini dimasa datang, misalnya dalam rangka pengembangan kebutuhan penyiaran digital selanjutnya. Pemerintah juga memiliki kepentingan terhadap pemanfaatan digital deviden ini, untuk keperluan pengembangan telekomunikasi untuk kepentingan masyarakat seperti pada pengembangan e-government atau pada ketersediaan frekuensi untuk kepentingan kebencanaan. Kepentingan ini juga yang menyebabkan Pemerintah tidak terlalu terjebak pada perdebatan kepentingan terkait pilihan single dan hybrid serta pada ada atau tidaknya praktek monopoli penyiaran.

Perdebatan pilihan single atau hybrid, serta ada tidaknya praktek monopoli harus disingkirkan dengan memperhatikan perhitungan teknis pembagian penggunaan frekuensi digital di setiap wilayah siar. Bagaimanapun model migrasi digital yang akan digunakan di Indonesia adalah yang paling sesuai dengan kebutuhan masyarakat akan materi penyiaran. Bisa jadi akan ditemukan model migrasi digital yang khas Indonesia yang justru bisa menjadi contoh baginegaralainyangselamaini hanyaterpaku pada penggunaan model single atau multi mux di negaranya masing-masing. Untuk itu penyelenggaraan model migrasi digital 
harus sesuai dengan konstitusi. Mengingat frekuensi penyiaran merupakan sumber daya alam yang terbatas maka negara perlu menguasai dan menggunakannya untuk sebesar-besarnya kemakmuran masyarakat. Kepentingan ekonomis harus menghormati pertimbangan konstitusi dan persyaratan teknis digitalisasi penyiaran yang legal formalnya termuat dalam undang-undang yang mengatur mengenai penyiaran.

\section{Penutup}

Kebijakan digitalisasi penyiaran di Indonesia, menjadi salah satu bagian dari sekian banyak kebijakan penggantian regulasi penyiaran. Oleh karena itu, penyusunan dan pembahasan kebijakannya menjadi salah satu materi dari seluruh materi penyusunan dan pembahasan RUU Penyiaran. Kebijakan digitalisasi penyiaran menjadi salah satu materi yang cukup alot dalam penyusunan dan pembahasan RUU Penyiaran. Penyusunan dan pembahasannya sudah dilakukan sejak DPR periode 2009-2014, namun hingga masa tugasnya berakhir, materi digitalisasi penyiaran belum dapat diputuskan.

Kontestasi perdebatan kepentingan dalam merumuskan kebijakan tentang digitalisasi penyiaran di Indonesia antara DPR periode 2009-2014 dengan Pemerintah, dilatar belakangi pertarungan kepentingan publik atau lembaga penyiaran. Tekanan lembaga penyiaran kepada Pemerintah saat itu didasari kepentingannya, terkait dengan telah ditetapkannya lembaga penyiaran sebagai pemenang lelang penyelenggara multipleksing dan investasi infrastruktur penyiaran yang telah dilakukan dan keuntungan yang akan dapat diperolehnya sebagai pengelola multipleksing. Sedangkan bagi DPR periode 2009-2014, kepentingan publik dalam mendapatkan layanan penyiaran menjadi landasan utama dalam penyusunan regulasi penyiaran.
Kontestasi perdebatan kepentingan dalam merumuskan kebijakan tentang digitalisasi penyiaran antara Komisi I dengan Baleg pada DPR periode 20142019, berkaitan dengan pilihan kebijakan single atau hybrid mux dalam pengelolaan multipleksing. Baleg menilai model migrasi single mux berpotensi untuk memunculkan praktek monopoli penyelenggaraan multipleksing yang dilakukan oleh lembaga penyiaran publik. Baleg juga menilai infrastuktur lembaga penyiaran publik sudah banyak yang berusia tua dan tidak mampu untuk melayani kebutuhan lembaga penyiaran swasta. Sedangkan Komisi I menilai frekuensi penyiaran merupakan sumber daya alam terbatas yang harus dikelola negara untuk kemakmuran masyarakat. Pemerintah diwajibkan untuk menyusun peta alokasi frekuensi dan ASO di setiap wilayah siar, tarif penyelenggaraan multipleksing, dan mewajibkan kepada lembaga penyiaran-untuk melakukan kesiapan baik infrastruktur maupun konten penyiaran. Sedangkan penyelenggara multipleksing diserahkan kepada lembaga penyiaran publik.

Kontestasi kepentingan dalam perumusan kebijakan digitalisasi penyiaran di Indonesia, seharusnya bersumber dari upaya pemutakhiran kepentingan masyarakat dalam mendapatkan penyiaran. Model migrasi penyiaran harus berangkat dari kepentingan masyarakat dalam mendapatkan materi penyiaran di setiap wilayah siar. Masing-masing wilayah siar pasti memiliki kebutuhan layanan siaran dan model migrasi yang berbeda.

Pemerintah telah memberikan solusi strategis untuk mengatasi perdebatan single dan hybrid mux. Solusinya menekankan pada kepastian hitungan peta alokasi frekuensi di setiap wilayah siar, digital deviden yang diperoleh, dan pengembangan industri 
lembaga penyiaran di kemudian hari. Mungkin solusi ini sekaligus juga bisa menjadi satu model migrasi yang khas Indonesia yang dapat dicontoh oleh negara lain dalam memilih model migrasi digital yang cocok buat negerinya. Selain itu, lembaga penyiaran juga perlu memahami kemajuan teknologi konvergensi media dan inovasi sumber serta distribusi layanan konten penyiaran yang perlu formulasikan juga dalam kebijakan digitalisasi penyiaran di Indonesia.

Hadirnya kebijakan digitalisasi penyiaran di Indonesia, tentunya akan menjadi dasar dari semua pemangku kepentingan penyiaran untuk menjalankannya. Lembaga penyiaran pasti harus mengikuti dan mengadaptasi dengan kepentingan-kepentingan yang selama ini dipertahankannya. Di balik itu semua, justru ada kepentingan yang sesungguhnya sangat besar yang harus terpenuhi yaitu penyiaran untuk kepentingan kesejahteraan masyarakat, bangsa, dan negara Indonesia, sebagaimana intinya termuat dalam konstitusi negara kita. Untuk itu DPR bersama Pemerintah, harus segera membahas RUU Penyiaran agar kepentingan masyarakat, bangsa, dan negara Indonesia benar-benar dapat terwujud.

\section{DAFTAR PUSTAKA}

Almond, Gabriel A. dan Powell, G. Bingham, eds., 1992. Comparative Politics Today: A World View: Edisi-5. New York: Harpes Collins.

Baksin, Askurifai, 2013, Jurnalistik televisi Teori dan Praktek, Bandung: Penerbit Simbiosis Rekatama Media.

Budiman, Ahmad 2015, Model Pengelolaan Digitalisasi Penyiaran di Indonesia, Jurnal Politica Volume 6 Nomor 2, Agustus 2015, Jakarta: Pusat Pengkajian Pengolahan Data Informasi Setjen DPR RI.
Haryanto, Ignatius, 2014, Jurnalisme Era Digital Tantangan Industri Media Abad 21, Jakarta: Penerbit PT Kompas.

Kellner, Douglas, 1990, Television and the Crisis of Democracy. Boulder, Colorado: Westview Press, Inc.

Maholtra, Naresh, (2002), Basic Marketing Research: Applications to Contemporary Issues, $5^{\text {th }} \mathrm{Ed}$, London: Prentice Hall.

Maiwan, Mohammad, 2016. Kelompok Kepentingan (Interest Group), Kekuasaan dan Kedudukannya dalam Sistem Politik: Jurnal Ilmiah Mimbar Demokrasi Volume 15, Nomor 2, April 2016.

Rakhmat, Jalaludin, 2004, Metode Peneitian Komunikasi, Bandung: Remadja Rosdakarya.

Shariar, Ary (ed), 2011, Kajian Konvergensi Teknologi Informasi Komunikasi, Jakarta: BPPT.

Sumartias, Suwandi dalam Budiman, Ahmad, 2016, Kesiapan Lembaga Penyiaran Melaksanakan Digitalisasi Penyiaran, Jakarta: Balai Pustaka.

Yin, Robert K., 2008, Studi Kasus: Desain $\mathcal{E}$ Metode, Jakarta: Rajawali Pers.

Sekretariat Jenderal DPR RI, Risalah Rapat Panja RUU Penyiaran Komisi I DPR RI, tanggal 2-7-2015

Rapat Panja RUU Penyiaran di Komisi I DPR RI, 19 April 2016.

Sekretariat Komisi I DPR, Laporan singkat Intern Panja RUU Penyiaran pada tanggal 16 Januari 2012.

Laporan

Kronologis Perjalanan Perumusan RUU Penyiaran 2010-2016.

Undang-Undang Nomor 32 Tahun 2002 tentang Penyiaran. 